\title{
The Leadership Analysis of Mangkunegara IV in Millennial Era
}

\author{
Novia Wahyu Wardhani ${ }^{1}$, Sabar Narimo ${ }^{2}$, Sri Hartatik ${ }^{3}$ \\ \{noviawahyu@mail.unnes.ac.id ${ }^{1}$, sabar.narimo@gmail.com², vieyak@gmail.com³ \\ Universitas Negeri Semarang, Indonesia ${ }^{1,2,3}$
}

\begin{abstract}
Javanese leadership theory often discussed in the political constellation present time. Javanese leadership always refers to two poles, culture of Java Yogyakarta and Surakarta. This paper specifically examines about leadership of Mangkunegaran IV associated with leadership in millennial era. This research using qualitative methode with phenomenology approach. The data source is obtained from observations, interviews and documentations. The data analysis using software nvivo 12 plus. The Resluts are Javanese leadership in millennial era still relevant for be created guidelines, because the concept of leadership which is flexible can be used from one generation to other generation. Leadership of Mangkunegaran IV that used as concept of millennial leadership is leadership not from ancestry but be formed through learning, the leaders can become role model, inovative in the development programs and welfare improvement, have independence and spirit of entrepeneurship, develope loyalty through various communication media, have the bravery and never give up mindset and brave to get best decision for public interest or his group. As for the difference are exist from various shape of leadership wich practices as exsample shape of media that used.
\end{abstract}

Keywords: Leadership, Mangkunegara IV, Millennial.

\section{Introduction}

Javanese leadership is a common thing to be discussed whether in study of literature, anthropology, as well as politic because leadership can not be separated from community culture to get power. But however, about leadership of Java in millennial era was not much discussed. Similarities and differences between Mangkunegaran IV era and Millenial Generation (Y) is an interesting topic for further study.

Millennial era is the era where technology develop so fast, making it easier for human living their life, one of the advantages is this technology can be used for media candidate leaders to get power. Millennials generation, also known as Y generation, is modern generation wich actively working, researching and inovative thinking about organization, have sense of optimism and determinsm for work competitively, openly and flexibly [1][2]. Millennials generation is able to work creatively and always have positive energy in various line, because of having high self confidence [3].

Several result of research explain that leadership in millennial era has the following caracteristics 1) Being able to be a good role model, 2) Having sense of responsbility, 3) Daring to take and willing to accept risk, 4) Having sense of belonging from the subordinate and sense of participation [1][4]. While Mangkunegara IV as one of the leadership references is the most prominent cadet leader, because as a statesman he has succeeded in delivering the 
Mangkunagaran cadet into a period that observers of Javanese culture called kalasumbaga (golden age). Mangkunegara IV takes the basis of 3 things that humans must have in maintaining their self-esteem as human beings, namely position, wealth, and intelligence. The strengths and advantages of Mangkunegara IV, which will be reviewed one by one in analyzing leadership in the millennial era in various forms.

\section{Method}

This is qualitative research with phenomenology approach and literature studies. Phenomenology is used to see phenomena drawn in the present. This aims to with steps of interpretation of leadership phenomena from 2000 to 2019, and then through dialouge with reslut of literature studies about Msangkunegaran IV and commit to deep reflection for to reach appropriate conclusion. The purpose of this research is to analysis of leadership of Mangkunegaran IV in Millennial era. The data source obtained from observation that conducted in 2015-2019, interview with public figures and documentation. The data analysis using nvivo 12 plus for simplify researcher to data reduction, presentation, and draw the conclusion.

\section{Reslut and Discussion}

\subsection{Mangkunegara IV}

Mangkunegara IV was born on 1 Sapar, 1736 Jimakir windu Sancaya or $3^{\text {rd }}$ March 1811 in Dalem Hadiwijayan, Surakarta. When was born, Mangkunegaaraan IV has name Raden Mas (R.M) Sudiro. He was seventh son of Kanjeng Pangeran Harya Hadiwijaya I. He was grandchild of Bandara Raden Mas Tumenggung Harya (R.M.T.H) Kusumadiningrat. His mother has name Bandara Raden Ajeng (B.R.A) Sekeli, has daughter of KGPAA (Kanjeng Gusti Pangeran Adipati Arya) Mangkunegara II.

Leadership of Mangkunegara IV bring Mangkunegaran in the golden era with various kinds of development. Mangkunegaran IV has reached of maturity in several line since before to be king of Mangkunegaran. Therefore, after becoming king, Mangkunegara immediately take the initiative in several sector of politics, government, economy, social then art and culture [6].

KGPAA Mangkunegara IV was king who has strong personality, great goals, extensive insight, authority in the military, ability in the government, deep sense of religion and art and culture. With the capability and his experience, after he get the position, he quickly takes initiative in politic, government, economic, social, art and culture etc. He has absolute autonomy about internal affairs as well as Sunan Surakarta and Sultan Yogyakarta. He was thought reserver a right to organize his government, organize his people, guarantee tranquility and their well-being as leaders.

KGPAA Mangkunegara IV had been ruling for 28 year, start by 1853 until 1881. At the time his ruling, Mangkunegara IV start to change government organization with estabilish departement outside Kasentanaan and Legiun wich named Kawadanan woh lead by a official, called Wadana. And then legitimacy his domain and expand his territory to Sukawati (Sragen) area, assisted the British government in defeat of Sultan Yogyakarta rebellion. All the effort be used for prepetuate his position as king, so that it can be more improve Mangkunagarab temple, such as legacy from the former kings. 
Mangkunegara IV never forsake doctrin of his ancestor. Was proved in several his literature work, narrated ancestor as role models. This work includes the following Serat Wedhatama to narate "Wong Agung" which is the panembahan senopati. Furthermore, Mangkunegaran was create Serat Tripama as moral doctrine which was made basic reference of idea for people to understand and to appreciate masterpieces his ancestor.

Several exsemplary of ancestor be created reference and motivation to develop of Mangkunegaran. Moreover, exsemplary of ancestor also created spirit and education for soldiers, officials and his people. This aims to together develop Mangkunegara to be great, superior, and different with another kingdom. At that time, Mangkunegaran had become extraordinary kingdom, and had great military as characterize of Mangkunegaran be compared with Kasunanan Surakarta and Kasultanan Yogyakarta.

Mangkunegaran was died on 5th September 1881, at 70 years old in Surakarta, he was buried in Astana Girilayu. After Mangkunegaran died many respons, such as C.A.L.J Jeekel Residen of Surakarta, on his letter to Governor-General, September 1881 that said "not even as the leader who has extraordinary ability, but also as an exsample which seldom to find in their circle, who has enthusiasm and capable to work systematically. He really wonderful to apply european methode". Moreover, Mangkunegaran IV was important for Dutch government, as mentioned by Colonel Verslag in his report on 1882, with his passing, the dutch government deepest condoleness to a famous indigenous figure, a decent called honored person, a loyal and keeping promises, a head of government which capable, strong determination and hard worker [5].

\subsection{Analysis Leadership of Mangkunegara in Millenial Era}

\subsubsection{Leadership}

First, the leaders are not from congenital of birth but rather be thought out and be prepared [6]. Mangkunegaran IV was king that was not descendant from Mangkunegaran III, but as brother from Mangkunegaran III. He was prepared by his grandfather to be leader beacuse his intelligence and has many superiorities since childhood. He was nurtured with principality education and also strong ......... Even though he has knowledge in administration and good religion. After grown-up he become candidate leader who has supported by Netherlands. He appointed based on the decree 16th Agustus 1857 at 46 years old [7] and for more approved of the legality of appointed, he was married to Raden Ayu Dunuk, as Mangkunegaran III firstborn with queen consort from Suryamijayan. The leadership in millennial era, the leaders also to be prepared. They grow up as leaders are not because descendant but created by cricle, the exsample is the elected of local leaders from nurturning of political party as their political circle, be form by their experience in society and legitimized by popular vote.

Second, the leader should be able to role model for their subordinate, so that to build the good society and to create effectieness in development, because expected to excited from millenials toward their leader [8]. Mangkunegara IV was also king who provide advices or doctrine wich good for his people, that he wrote in literary work moreover thus far be used such as Serat Wedhatama, Tripama, Wirawiyata, Manuhara, Nayakawara, Yogatama, Parimnita, Pralambang Lara Kenya, Langenswara, Sriyatna, Candrarini, Paliatma, Salokatama, Darmawasita and etc. The leader in millennial era with democratic general election have been raised of enthusiasm for following on performance the leader in development. They also have role model in their leadership era such as Gusdur about pluralism.

Third, the inovative leader because inovation are important in organization who they lead [9] (Rachman dan Jakob, 2018). According to Pringgadigda [5], Mangkunegaran was an originator principle of modern plantation economy. In the security sector, he establishes cop 
unit that receives the case reports, operate letter of instruction and help the community. The cop at that time were not work alone but they have several subordinate, that is carik, headmen, langsir (Hussar armed with spears) wibasana and wadana gunung [10]. In the cop also have intelligence wich called margatama. Margatama on duty reporting all the things wich suspicious. Margatama have subordinate, that is margayuda nagara and juru karya peksa with subordinate margayuda desa [11].

Mangkunegaran IV was also estabilish educational institusion Legiun Mangkunegaran with take all the rules and procedures from Europe which is translated to Java langugae and named after "Layang Pranatan Soldat Sekul". This translation procedure of solider asisted with his friend, named Carl Friedrich Winter a son of Java language translator's, Johannes Wilhelmus Winter.

Leaders in millennial era as well have many inovation, such as Ridwan Kamil who has inovation to develop smart city progam, trash bank, and kampong hijau (green village). Joko Widodo with Kartu Indonesia Sehat (KIS) or health insurance and KIP (Kartu Indonesia Pintar) or educational assistance. Anis Baswedan with naturalization rivers to prevent flood and etc.

a. The leaders in millennial era supporting independence and spirit of entrepreneurship [12]. Mangkunegara IV was also has principal of independence and spirit of entrepreneurship, proven he has large coffee plantation that managed like Europe plantation in empire territory. He has to develop agricultural exports especially coffee and cane. He also owns sugar factory in Colomadu and Tasikmadu which the machines are imported from Eroupe and the products exported to Europe. He also has many establish economic cooperation which is profitable beetwen Java and Dutch. The cooperation realized with capital aid from Nederlandsche Handelmaatschappij in Semarang and Maatschappij, what makes sugar factory in Colomadu and Tasikmadu to thrive. This two factory were become pilot factory, which visited a lot officials and foreigners [13]. Furthemore sugar factory, also was established indigo processing plant on 1880 which the product export to Europe [14]. The plants obtained for supporting economic improvement beside cane are quinine and nutmeg which planted on the slopes of mount Lawu. The other business was sisal factory in mentotulakan, cake factory in Polokarto, brick and tile factory in Kemiri, and forest products in Wonogiri. The leaders in millennial era also like Mangkunegaran IV, they have big family business like Jokowi with furniture company, Hari Tanoe Sudibyo with MNC group, and many more.

b. The leaders in millennial era use communication devices for strengthen them leadership. Likewish Mangkunegara IV in communication sector, in 1863 there was a postal service. The postal services established for facilitate the communication between Mangkunegaran with his region and the dutch government. The postal services not only in domestic area but be able send a message to Netherland. In 1976 the telegram service was opened [14].

c. The millennial leaders have to be brave and never give up [19]. Mangkunegara IV was leader who honored. The greatness, he did opposition through tulisan pena, it was enough making the colonialist retreat. This way, as an exsample main attitude in uphold ethic of war according to Java that is "nglurug tanpa bala, digdaya tanpa aji, dan menang tanpa ngasorake". The victory reached by chivalrous, without involving many people, without weapons which kill people and never embarras the enemy. Moreover, Mangkunegara IV reinforce the punishment for bribery case with act issued "Layang Pranatan on the Ban for Bribery of 1854", the content are:

a. The person who want position such as ngabei, demang, rangga and bekel, forbidden to bribe with money or other objects which have value.

$b$. If success to get position, forbidden to ask for fees from subordinates. 
c. Whoever breaking this instruction, who give or recieve bribes, will be get equitable punishment

The leadership in millennial era prioritize to uphold the justice and combating corruption. Since 1995, International Transparation has been publish annually the Corruption Preceptions Index (CPI) wich ranks countries.

d. The leaders have a courage do the best to make decision for public interest and their group [15], [16]. In the mids of an escalate apanage land rent to Eouropean plantation businessman. He was made controversial policies. To recall the apange lands wich was rented to European businessman. And then he manages it by himself for farmland. Those owners of land right gave compensation. This matter for prosperity his people likes as the explantion to Surakarta Surakarta. The explanation, contains about apange land recalls and the salary to familiy on March, 281871 [11]. Mangkunegaran IV to implement his instruction, care about fate of people, so as he concern about law and corruption. Mangkunegara IV pressing to Resident of Surakarta for change the law to indigenous. This matter was followed up Resident of Surakarta with sending a letter to Governor-General, No. 3515 Surakarta, on April 25, 1873, which for in the Kasunanan and Mangkunegaran formed Pradoto of Regency. The Dutch East Indies approve the Resident proposal with Government Secretary Decree No. 1302 Batavia, on 9 Juni 1873. With the court of afdeling-afdeling pradoto, accordingly since 1873, the court issue to indigenous was taken over pradoto of indigenous and not exceed three month has beem handled.

\section{Conclusion}

The leadership of Mangkunegara IV in millennial era have similarity and difference. The similarity are have concept of leadership is not from descendant but also can be form, have exemplary, innovative in development programs and welfare improvement, have independence and spirit of entrepreneurship, develop loyalty through various media communications, have the bravery and never give up mindset and brave to get best decision for public interest or their group. As for the difference are exist from various shape of leadership which practices as example media form that used.

\section{References}

[1] A. Ambarwati and S. T. Raharjo, "Prinsip Kepemimpinan Character of a Leader pada Era Generasi Milenial," Philanthr. J. Psychol., vol. 2, no. 2, pp. 114-127, 2018.

[2] M. D. Egbert and J. Pérez-Mercader, "Adapting to adaptations: Behavioural strategies that are robust to mutations and other organisational-transformations," Sci. Rep., vol. 6, p. 18963, 2016.

[3] A. D. Chullen, C. L., Dunford, B. B., Angermeier, I., Boss, R. W., \& Boss, "Minimizing Deviant Behavior In Healthcare Organizations: The Affects Of Supportive Leadership And Job Design," J. Healthc. Manag., 2010.

[4] D. Peramesti, Ni Putu Depi Yulia dan Kusmana, "Kepemimpinan Ideal Pada Era Generasi 
Milenial," J. Transform. Pemerintah., vol. 10, no. 1, 2018.

[5] Pringgadigda, Dhoemadhos saha Ngrembakanipoen Pradja Mangkoenagaran. Surakarta: Mangkoenagaran, 1939.

[6] E. E. Bell, "Understanding African American males' schooling experiences: A qualitative inquiry," Qual. Rep., vol. 20, no. 8, pp. 1260-1269, 2015.

[7] Politiek Verslag van de Residentie Soerakarta (PVRS) over het jaar, Arsip Karesidenan Surakarta No. 113. 1857.

[8] W. Wu, F. Tang, X. Dong, and C. Liu, "Different identifications cause different types of voice: A role identity approach to the relations between organizational socialization and voice," Asia Pacific J. Manag., vol. 32, no. 1, pp. 251-287, 2015.

[9] E. Rachman, Eileen \& Jacob, "Pemimpin Milenial," 2018. [Online]. Available: https://www.experd.com/en/articles/2018/05/965/pemimpin-milenial.html.

[10] I. Santosa, Legiun Mangkunegaran (1808-1942). Jakarta: Kompas, 2011.

[11] Margana, Kraton Surakarta dan Yogyakarta 1769-1874. Yogyakarta: Pustaka Pelajar, 2004.

[12] D. Yoon, J. Jang, and J. Lee, "Environmental management strategy and organizational citizenship behaviors in the hotel industry: The mediating role of organizational trust and commitment," Int. J. Contemp. Hosp. Manag., vol. 28, no. 8, pp. 1577-1597, 2016.

[13] D. Locomotief, Mangkunegara IV. Semarang: Surat Kabar Semarang, 1981.

[14] Daryono, Etos Dagang Orang Jawa: Pengalaman Raja Mangkunegara IV. Yogyakarta: Pustaka Pelajar, 2007.

[15] L. Mogotsi, I. C., Boon, J. A., \& Fletcher, "Modelling The Relationships Between Knowledge Sharing, Organisational Citizenship, Job Satisfaction And Organisational Commitment Among School Teachers In Botswana," African J. Libr. Arch. Inf. Sci., vol. 21, no. 1, pp. 41-58, 2011.

[16] K. Kamani, S. M. H., \& Namdari, "A Study Of The Relationship Between Organizational Justice And Support And Organizational Citizenship Behavior,” Int. J. Arts Sci., vol. 5, no. 6, 2012. 